OPEN ACCESS

Edited by:

Marianne Holmer,

University of Southern Denmark,

Denmark

Reviewed by: Perumal Karthick,

Sea6 Energy Pvt Ltd., India

Mads Solgaard Thomsen,

University of Canterbury, New Zealand

${ }^{*}$ Correspondence: Hartvig Christie

hartvig.christie@niva.no

Specialty section:

This article was submitted to Marine Ecosystem Ecology,

a section of the journal

Frontiers in Marine Science

Received: 01 September 2018 Accepted: 07 February 2019

Published: 22 February 2019

Citation:

Christie H, Andersen GS,

Bekkby T, Fagerli CW, Gitmark JK, Gundersen H and Rinde E (2019) Shifts Between Sugar Kelp and Turf Algae in Norway: Regime Shifts or

Fluctuations Between Different Opportunistic Seaweed Species? Front. Mar. Sci. 6:72 doi: 10.3389/fmars.2019.00072

\section{Shifts Between Sugar Kelp and Turf Algae in Norway: Regime Shifts or Fluctuations Between Different Opportunistic Seaweed Species?}

\author{
Hartvig Christie*, Guri S. Andersen, Trine Bekkby, Camilla W. Fagerli, Janne K. Gitmark, \\ Hege Gundersen and Eli Rinde
}

Norwegian Institute for Water Research, Oslo, Norway

Around year 2000, sugar kelp (Saccharina latissima) forests were observed to disappear in southern parts of Norway, being replaced by mats of turf algae (i.e., filamentous ephemeral algae) loaded with sediments. Among more than 600 stations covering 35 $000 \mathrm{~km}$ of coastline, about $80 \%$ on the Skagerrak coast and about $40 \%$ on the North Sea coast were dominated by turf. Various types of turf algae replaced S. latissima in a discontinuous pattern. This large spatial scale event was reported as a possible irrevocable regime shift, not caused by a single factor but related to multiple stressors, where eutrophication and ocean warming were proposed to be the most important. Recent observations have however, revealed that the seabed state has flipped back and forth between sugar kelp and turf algae in several areas and on temporal scales spanning from seasons to years. The relative abundance of $S$. latissima at monitoring sites at the Norwegian southern coast has fluctuated dramatically during the last 12 years, varying from sparse to common at several of these sites. In 2016, sugar kelp abundance had increased in more than half of the sites, compared to earlier years. Our monitoring data as well as other field observations and field experiments question the regime shift paradigm. Although traditionally considered as a perennial macrophyte, several of our studies indicate that sugar kelp possesses many of the characteristic traits of an opportunistic species, such as high dispersal potential and colonization rate, which enables the species to rapidly colonize available substrate. However, where turf algae persist, space for recolonization of sugar kelp will most likely be minor. In this paper we explore the spatial and temporal shift dynamic between sugar kelp and turf algae based on monitoring data and other studies. Based on a synthesis of mapped fluctuations between the two states, and studies on sugar kelps recolonization abilities, we discuss prerequisites and drivers for an irrevocable regime shift or a continuation of natural fluctuations, as well as possible mitigation actions.

Keywords: sugar kelp, turf algae, regime shift, flips back, opportunistic algae, eutrophication 


\section{INTRODUCTION}

An increasing global concern related to regime shifts from perennial foundation kelp species to turf algae (i.e., filamentous, ephemeral algae) have recently initiated "dramatic" headlines in the scientific literature, such as "Turf wars" (O'Brien and Scheibling, 2018) and "Rise of turfs: a new battlefront....." (Filbee-Dexter and Wernberg, 2018). These papers (and recent references therein) relate large-scale shifts, earlier described as eutrophication effects (Duarte, 1995; Nixon, 1995; Valiela et al., 1997; Schramm, 1999; Cloern, 2001), to be the result of the combined influence of a complex multifactorial set of direct and indirect stressors (see Filbee-Dexter and Wernberg, 2018), where climate change may play an important role. Norwegian kelp forests are among the many global examples of ecosystems that have been known to experience such shifts. The first shift from sugar kelp (Saccharina latissima) to turf algae was reported in the early 2000's (see Andersen et al., 2011; Moy and Christie, 2012). The concern for the declining distribution of sugar kelp initiated monitoring and scientific studies in southern Norway with focus on this species. The comprehensive sugar kelp project 2005-2008 covering a high number $(>600)$ of sites has been followed by a more site-specific monitoring program, which is still running. Data from more than 15 scientific reports (in Norwegian) was synthesized in the final report from "the sugar kelp project" (Moy et al., 2009). The report concluded that the declines of S. latissima were discontinuous within both small and large spatial and temporal scales, but an overall evaluation concluded that the loss of kelp was considerable both at the southeast coast and the southwest coast. Moy and Christie (2012) classified the ecological state of sugar kelp in five quality classes, indicating how the degree of kelp loss varied both between and within regions. Although extensive dominance by turf algae, S. latissima were observed to occur sparsely or more abundant (between poor and god classification) at about $60 \%$ of the sites.

Andersen et al. (2011), Andersen et al. (in press), and Moy and Christie (2012) concluded that the heavy growth of epiphytic algae on S. latissima kelp lamina reduced light penetration below critical levels and thus caused kelp death. Turf algae replaced kelp on the seafloor, trapped inorganic and organic sediments, and prevented recruitment and recovery of the kelp (Moy and Christie, 2012). The dominant turf algae in the Skagerrak coast (southeast Norway), with short dominating turf algae (such as Cladophora spp, Heterosiphonia japonica, Trailliella intricata), differed from of the larger turf algae species within the North Sea coast (south-west Norway, e.g., Spermatochnus paradoxus), dominating the ephemeral vegetation during the summer season. The reported shifts were discontinuous in space and time (Moy et al., 2009; Moy and Christie, 2012) and the causes to the observed patterns were difficult to identify. Areas with high water movement, caused by waves and currents, were in these studies suggested to be unfavorable for the turf algae. This relationship was reported earlier by Pihl et al. (1999) from the Swedish west coast, and confirmed by Bekkby and Moy (2011), who reanalyzed the Norwegian sugar kelp monitoring data and developed spatial distribution models. After visiting 605 stations in southern Norway (2005-2008), Moy and Christie
(2012) estimated that a shift from kelp to turf dominance had occurred at approximately $80 \%$ of the Skagerrak stations and at approximately $40 \%$ at the North Sea stations. Bekkby and Moy (2011) modeled that approximately 50\% of the sugar kelp forests areas within the Skagerrak area was lost. More frequent monitoring of 10 stations between 2005 and 2008 (Moy and Christie, 2012), showed persistence of turf algae dominance at many sites, but also documented recovery of S. latissima and temporarily (seasonal) recovery in spring, often followed by increased epiphytic load and turf algae dominance throughout summer. The large spatial and temporal variation in kelp and turf algae abundance along the Norwegian coast, initiates the following hypothesis about their possible development; the turf algae dominated sites may persist for several years, the turf algae sites might recover to sugar kelp dominance, or the sites might fluctuate between years with dominance of either one or the other of the two groups (Figure 1).

On a global scale, the distribution of perennial macrophytes (seagrasses and larger seaweeds) shows decreasing trends (Waycott et al., 2009; Araujo et al., 2016; Krumhansl et al., 2016). The reported shifts from sugar kelp to turf algae in southern Norway has contributed to this general trend. Sugar kelp has traditionally been considered as a stable perennial kelp species (e.g., Bekkby and Moy, 2011; Araujo et al., 2016) with a life span of about 3 years and with spore production each winter. In their review, Filbee-Dexter and Wernberg (2018) stated that: «Shifts from kelp forests to turfs have not shown recovery, but reefs have remained in a degraded turf state». This is certainly a valid statement so far, with exception for the annual kelp Undaria pinnatifida (South et al., 2017). But looking with "new eyes" on the data from Moy and Christie (2012) and relating these also to more recent relevant studies from Norway (not easily accessible reports in Norwegian) has made us question this statement and the idea of sugar kelp as a stable, perennial species. While flips in kelp systems mainly have moved from kelp to another less favorable state (Steneck et al., 2013; FilbeeDexter et al., 2016; Krumhansl et al., 2016; Filbee-Dexter and Wernberg, 2018) representing persistent regime shifts, several observations from southern Norway indicate that flips back to kelp may occur. The aim of this paper is (1) to explore the shift

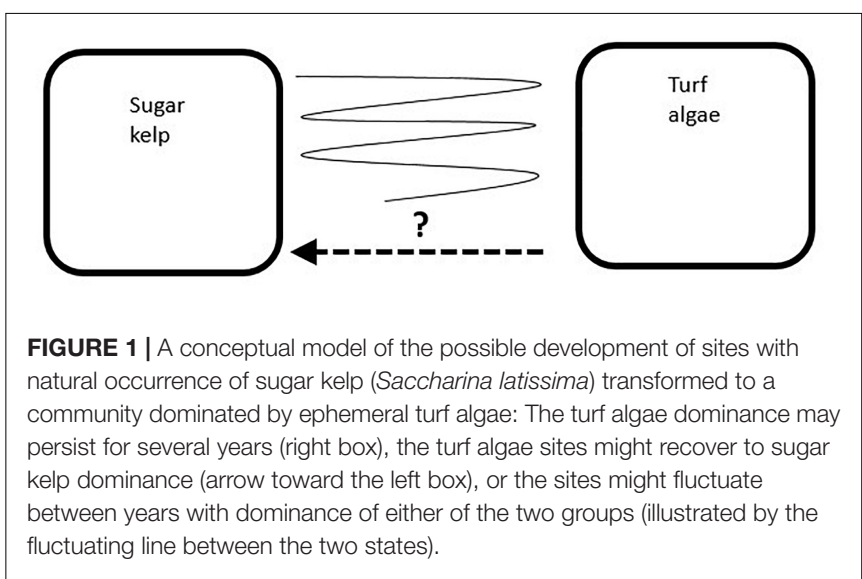


dynamic pattern at monitored stations, to assess the extent of recovery of sugar kelp at turf dominated stations, and to test any temporal trends in the fluctuations between the two groups, (2) explore, through data from previous studies, life history traits of sugar kelp important for recovery; and (3) to discuss prerequisites and drivers for potential irrevocable regime shifts to turf algae communities or the existence of natural fluctuations between sugar kelp and turf algae, considering both as opportunistic species. Understanding such dynamics will have implication for evaluation of mitigation actions. This paper will not try to highlight pressures behind the shift from kelp to turf algae, as this probably involve several physical, chemical, and biological interactions that even might work synergistically. A complete understanding of the drivers and the dynamics of these shifts is not possible based on analysis of monitoring data only, and demand complex further investigations.

\section{DATA COMPILATION AND ANALYSIS}

This study is based on available data from earlier published material (included data reports in Norwegian) from the 1990's and up to 2017. Most of the data were sampled within the projects "the sugar kelp project": 2005-2008; "the sugar kelp monitoring program": 2009-2012; and the monitoring program "ØKOKYST": 2013-2017. Data were available from several scientific reports (e.g., Moy et al., 2006, 2007, 2008, 2009), from a synthesis paper (Moy and Christie, 2012), and from recent monitoring reports (Fagerli et al., 2017; Naustvoll et al., 2018).

The main aim of the sugar kelp monitoring was to map the state of the sugar kelp forests (sugar kelp abundance versus turf algae abundance) and to detect possible changes in ecosystem state over seasons and years. Hence the data can be used to identify any continuous or discontinuous shift of the two states (kelp and turf) over space and time during the monitoring period. During the surveys in 2005-2008, more than 600 stations were recorded along the southern Norwegian coast (a complex coastline of $35000 \mathrm{~km}$ ) and classified as described below. If transects (mainly 0-20 m depth transects) were visited or different depths were recorded on some stations, the data from 5 to $6 \mathrm{~m}$ depth were used for the overall comparisons. All stations were in moderately wave exposed, or wave sheltered areas (SWM > 100000 in Isaeus, 2004, see Gundersen et al., 2011) rocky bottoms (bedrock, boulders, stones), which is where sugar kelp is expected to grow. Most of the stations had not been visited before, so expected presence of sugar kelp was estimated from 30 recordings in the 1980's and 1990's at sites where sugar kelp dominated from about $1 \mathrm{~m}$ and down to about $15 \mathrm{~m}$ depth (see Moy and Christie, 2012). Both the understory species and the species dominating the turf community varies along the depth gradient and between regions (south vs west, see Moy and Christie, 2012). Turf algae consisted mainly of ephemeral algae, with high abundance during summer and reduced abundance in the winter season.

In the early period of monitoring (2005-2008) the sugar kelp and turf algae abundance were determined by use of drop-camera (with depth sensor, operated from a boat), and only in a few cases by SCUBA diving. Diving was mainly done at selected sites that were revisited during years and seasons. The ecological status of each site was classified after a semi-quantitative abundance scale of sugar kelp (0: absent, 1: single specimen, 2: scattered, 3: common, and 4: dominating), combined with occurrence of turf algae (cf Moy and Christie, 2012). In subsequent programs (2009-2016) annual monitoring was continued at 10 stations in Skagerrak and along the North Sea coast (in the West). Dropcamera was replaced by dive surveys, where abundance of all macroalgal species (or taxa) was recorded semi-quantitatively by the identical 5-step scale as presented above. All visible species were recorded along fixed transects, approximately $0.5 \mathrm{~m}$ on each side of the diver's position, i.e., $1 \mathrm{~m}^{2}$ at each depth). Observations were made for every meter from 1 to $4 \mathrm{~m}$ below surface and for every second meter from 4 to maximum $30 \mathrm{~m}$ depth. The long-term monitoring of fixed sites provides an opportunity to document any ecosystem shifts, or fluctuations between sugar kelp and turf dominated communities. National reports from the monitoring programs document annual fluctuations in the cover of sugar kelp and indicates that the variation is negatively associated to the abundance of turf (Moy et al., 2009; Fagerli et al., 2017). Based on the annual monitoring data we aimed to assess the extent of kelp recovery from turf algae dominance, and to test if the abundance of turf influences the density of sugar kelp.

The spatio-temporal variability of S. latissima cover was analyzed with a linear mixed effect model. Data from $6 \mathrm{~m}$ depth, from $11 \mathrm{~m}$ monitoring stations, was selected for the analysis. Algal cover data from 74 species/taxa were accumulated and grouped together in one generic "turf" group based on their morpho-functional traits. Three factors were included in the model: cover of turf (fixed with one level), cover of the kelp L. hyperborea (fixed with 1 level) and year (fixed with 7 levels), and station (random with 11 levels). L. hyperborea was included in the model since they are often found at the same locations and may affect the abundance of sugar kelp. All possible interactions were included in the full model and Akaike's information criterion (AIC) was used for model selection. The linear mixed effect model "nlme" (Pinheiro et al., 2012) was applied for the analysis. We also performed an ANOVA of the cover values with the two fixed factors; group (i.e., turf or kelp, where kelp included both kelp species, L. hyperborea and S. latissima) and time (i.e., year), using station as a random factor. To further explore the relationship between kelp and turf algae, we also calculated Pearson's correlation coefficient between the recorded cover of all species, grouped as turf or kelp.

The basis for evaluation of sugar kelp dispersal traits, are data from former studies of recruitment and regrowth of sugar kelp on areas far from any sugar kelp spore sources have been used. Sugar kelp colonization and recovery rate has been recorded after removal of sea urchins inside a large barren ground area (Leinaas and Christie, 1996), where bottom substrates have become available after sea urchin mortality (Rinde et al., 2014; Christie et al., 2019) and on artificial reefs (Christie, 2011).

As a basis for understanding the recruitment and spreading potential of sugar kelp, we have used the experiments performed by Andersen (2013). This study recorded S. latissima recruitment 


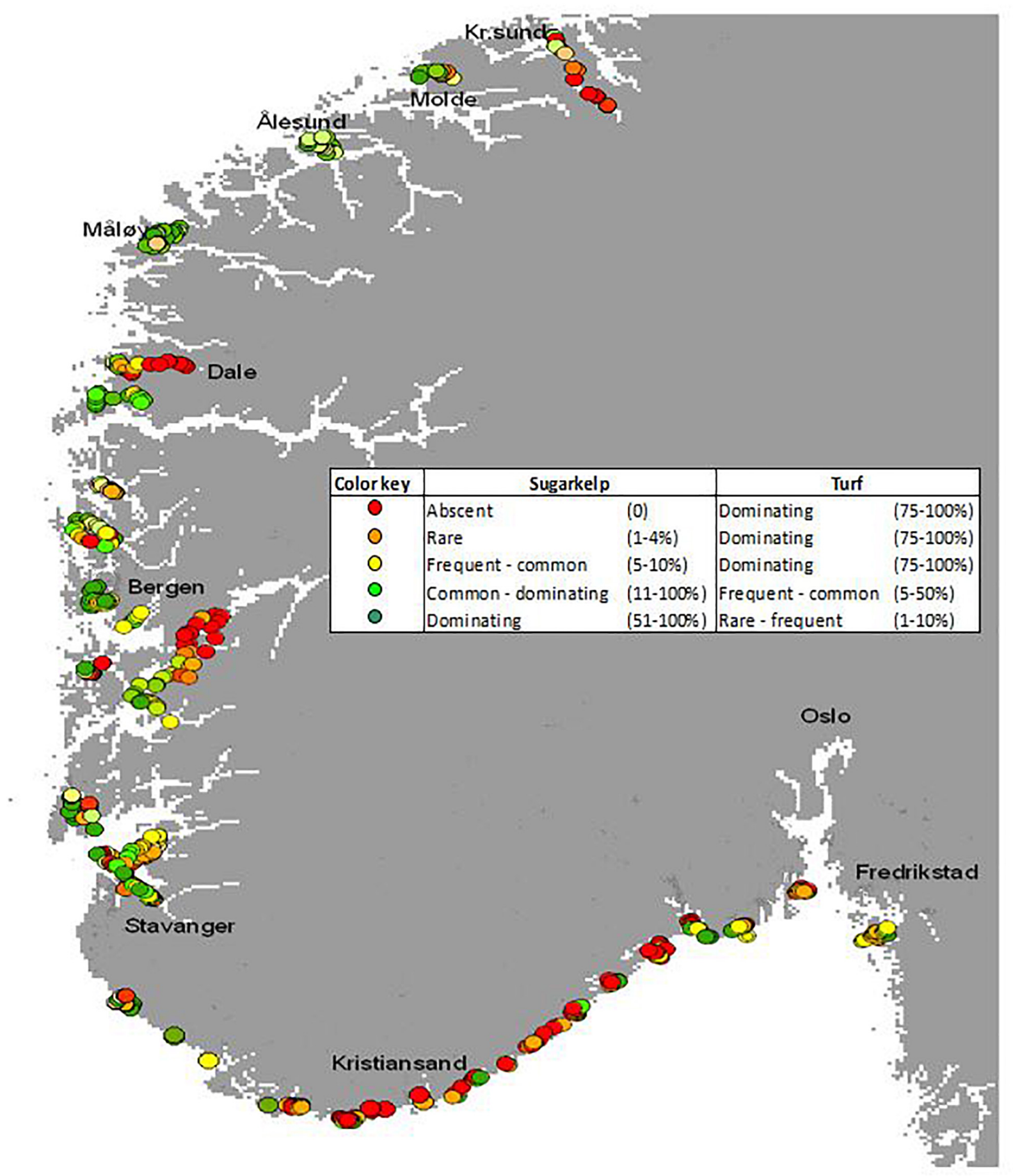

FIGURE 2 | Substrate coverage of both S. latissima and turf algae was recorded at more than 600 sites on the southern coast of Norway in the period 2005-2008. Semiquantitative abundance was determined using the following categories: absent, scattered (1-4\% coverage of available and suitable substrate), frequent (5-10\% coverage), common (11-50\% coverage), and dominant (51-100\% coverage). The state of each kelp site was evaluated based on the balance between the abundance of kelp and the abundance of turfs. These evaluations are indicated by the coloring, ranging from a good state with kelp domination (green) to a bad state with complete domination of turfs (red). Figure modified from Moy et al. (2009).

and how recruitment rate relates to the development of fertile tissue (sori) on adult kelp throughout a reproductive period. The seasonal differences in the extent of sori, recruitment and the time-related pattern (minutes to hours) of settlement and recruitment immediately following spore release was investigated combining both field and laboratory work. 


\section{RESULTS AND DISCUSSION}

\section{Spatial and Temporal Variation in Sugar Kelp Abundance}

The data from the survey period 2005-2008 indicate a complex spatial distribution pattern of kelp and turf along this long coastline (Figure 2), where red turf algae loaded with sediments dominated on the Skagerrak coast and longer brown filamentous algae dominated on the North Sea coast (Moy et al., 2009; Moy and Christie, 2012). This discontinuous distribution was to some extent explained by the degree of exposure to waves (Bekkby and Moy, 2011; Moy and Christie, 2012), but this relationship was not consistent. Temporal changes were found all along the investigated coastline but was more pronounced at the North Sea coast (Moy and Christie, 2012). The observations from the repeated samplings formed the basis for a conceptual model of the change in macroalgal composition (see Figure 4 in Moy and Christie, 2012) illustrating the decline of sugar kelp and the seasonal fluctuation of turf from dominant in summer and reduced in winter after 2002 in Skagerrak. There, a recovery of sugar kelp occurred during 2007-2008. The decline of kelp and shift to dominance of turf in the North Sea were recorded in 2006. In 2008 sugar kelp recovered to high abundance at the expense of turf algae. The recovery of sugar kelp was minor at Skagerrak due to persistence of turf algae loaded with sediments (Moy and Christie, 2012). Moy and Christie (2012) also showed the frequent coverage of perennial understory macroalgae that may serve as a substrate for sugar kelp spores, but that do not function as proper substrate when the sporophyte grows to larger size during summer leading to dislodgement (see O'Brien and Scheibling, 2018). This was assumed to cause a seasonal loss and variation in S. latissima abundance. The bad ecological status of sugar kelp in the Hardangerfjord in the early 2000's (Moy et al., 2007) contrasts to the conditions reported later (Husa et al., 2014; Sjøtun et al., 2015), indicating a later recovery of sugar kelp in this area, in line with the conclusions of Moy and Christie (2012) from other parts of the west coast.

\section{Shifts in S. latissima Abundance in Skagerrak and at the North Sea Coast 2005-2017}

More recent monitoring of 10 stations at the Skagerrak (southeast) coast and two stations at the North Sea (southwest) coast (Fagerli et al., 2017; Moy et al., 2017; Naustvoll et al., 2018) shows inconsistent changes in abundance of S. latissima between years and sites (Table 1, Figure 3). At the Skagerrak coast half of the stations showed improved growth and sugar kelp recovery compared to the status reported in the previous monitoring period (Moy and Christie, 2012, red dots in Figure 1). At most of the stations the abundance of sugar kelp has fluctuated between rare, frequent and common throughout the period of monitoring (Table 1), and even fluctuated between absent and to dominant at one site. There are large differences between the stations in development of sugar kelp and turf cover in the period 2009-2016 (Figure 3). Some stations have several alternations between absence and scattered occurrences of sugar

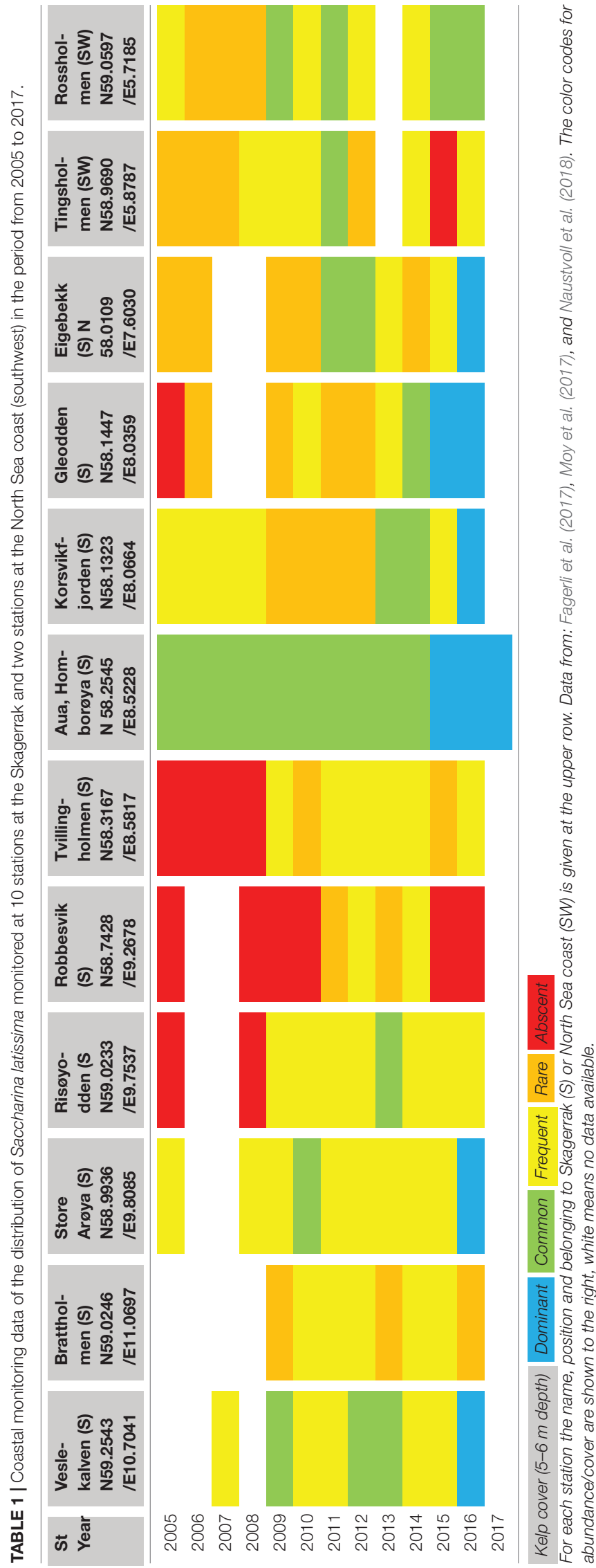




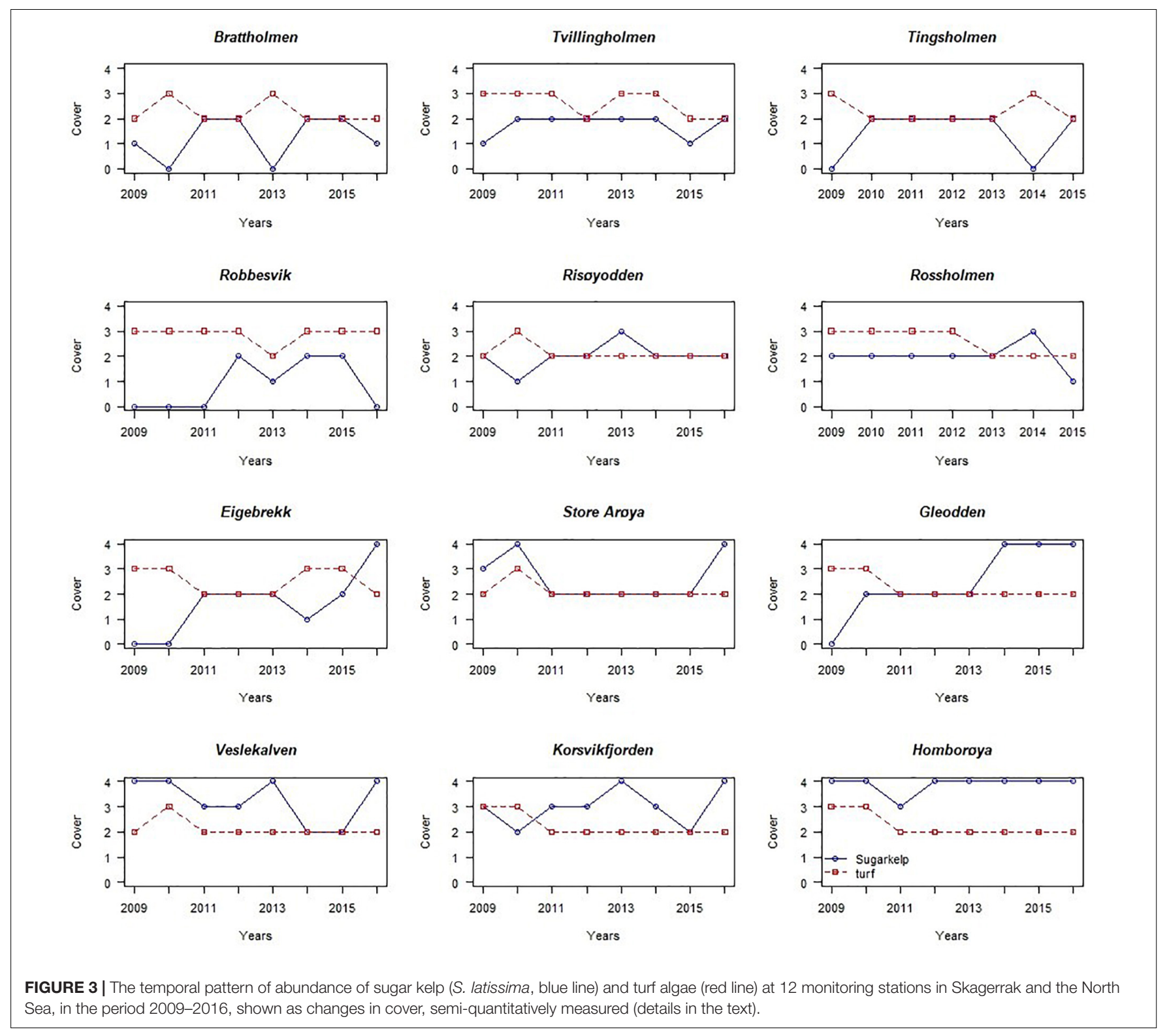

kelp (for example Brattholm). At these stations, and at Eigebrekk and partly Gleodden, turf algae and sugar kelp show a reverse pattern over time. These observations clearly document how sugar kelp can recover at earlier turf dominated sites, and that the fluctuations may occur frequently. The inconsistency between stations is too large to be explained only by temperature or other environmental factors (waves and nutrients, as was suggested by Bekkby and Moy, 2011). The shift to good condition at several stations in 2015 and 2016 should however, have been investigated closer. Taking advantage of such shifts in experimental studies of drivers are crucial to increase the understanding of the shift dynamics and the underlying mechanisms.

Also at the two stations in the North Sea (Tingsholmen and Rossholmen) the cover of sugar kelp and turf varied between the two stations and between years (Figure 3 and Table 1). Although the stations are situated within short distance, the temporal variation was different: the kelp increased from "scattered" to "common" at Rossholmen in 2015, but kelp was absent at Tingsholmen in 2014, despite scattered abundance in 2013 and 2015. Figure 3 and Table 1 shows that the abundance of kelp and turf shifts between years in an unpredictable pattern, indicating stochastic factors driving the abundance of this presumably opportunistic species in both ecoregions (see later). Five of the 12 stations had recovery from 0 coverage of kelp (combined with high abundance of turf) in the period 2009-2016 (i.e., Robbersvik, Brattholm, Gleodden, Eigebrekk, and Tingsholmen).

The linear mixed effect model identified significant effects of both the coverage of $L$. hyperborea $(p<0.001)$ and the abundance of turf algae $(p<0.0001)$ on the coverage of sugar kelp. A significant negative correlation (Pearson's correlation coefficient) were found between sugar kelp and turf algae cover $(-0.67, p<0.0001)$, also indicating a causal negative impact of turf 
on sugar kelp. The ANOVA analysis showed a significant effect of time $(p<0.0001)$ and of the interaction between time and group $(p=0.003)$, but not for the group factor alone $(p=0.07)$.

\section{S. latissima, an Opportunistic Species?}

Kelps have complex life histories where the large, sporophytes alternate with microscopic gametophytes via flagellated spores (planktonic dispersal stages). The production of spores in S. latissima is large, and kelp spores may disperse over great distances (Schiel and Foster, 2006; Cie and Edwards, 2011). Although most settle near the mother plants (Graham, 2003; Gaylord et al., 2006), large-scale oceanographic processes may serve as key drivers of connectivity between kelp populations. High reproduction, high dispersal rates, and high growth rate are typical traits of opportunistic species, as well as the short lifetime of S. latissima (Bartsch et al., 2008; Andersen et al., 2011).

Data from Leinaas and Christie (1996), presented in Figure 4, document a rapid recolonization of S. latissima to a small isolated island after removing sea urchins (Strongylocentrotus droebachiensis). As sugar kelp normally release spores in the winter season (Andersen, 2013) the small sporophytes start to grow in the spring and may be observed in early summer. The average density of small sporophytes was more than 470 per $\mathrm{m}^{2}$ (Figure 4, see also Leinaas and Christie, 1996). This finding is supported by more recent recordings of sugar kelp beds in areas where sea urchin densities are decreasing in northern Norway (Rinde et al., 2014; Christie et al., 2019).

A similar pattern of rapid recolonization of sugar kelp to available substrate was recorded at 12 artificial reefs deployed in an area dominated by sea urchins, with no kelp observed in the area. In July, 2006, these large artificial reefs made of concrete and plastic tubes were launched at about $10 \mathrm{~m}$ depth at Hammerfest (Barents Sea Norway, Christie, 2011). The recolonization pattern was recorded by diving and photo once or twice a year, for 4 years. After 3 months (October, 2006), mainly small filamentous algae and tubeworms had settled and could be identified at the reef structures. After the following winter and the recruitment season of sugar kelp, the first small kelp sporophytes were observed in April 2007. In July 2007 larger sugar kelps dominated, and the density of sugar kelp was approximately 30 individuals per $2.5 \mathrm{~m}$ of the plastic (PVC) tubes of the reefs (roughly about 60 per $\mathrm{m}^{2}$ ). The outer surface of the reefs was densely colonized with sugar kelp for almost 3 years (from autumn 2007 and until the summer of 2010) before sea urchins invaded the reefs and overgrazed the kelps.

Rapid recruitment of kelp on artificial substrate excludes the existence of a dormant spore banks on the substrate (Hoffmann and Santelices, 1991) as source of the spores. The rapid recruitment and high colonization rate of sugar kelp on the artificial reef structures clearly document that sugar kelp has a great ability to disperse, colonize, and recover kelp forests on available substrate if the conditions are suitable, even when the substrate is far away from a spore source population.

The study by Andersen (2013) revealed synchronous development of fertile tissue, high concentrations of viable spores, consistent settlement patterns and a relatively steady in situ recruitment on clean substrate throughout the winter

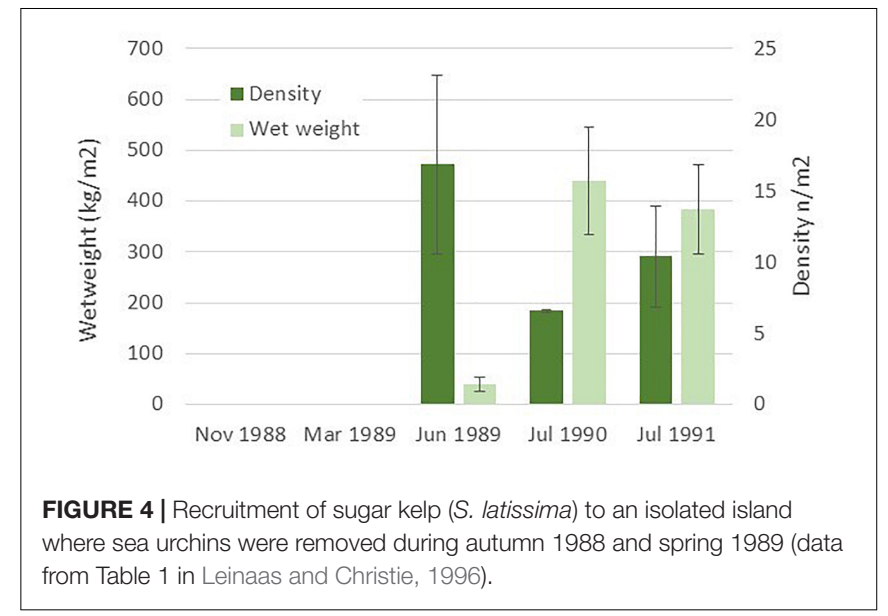

months. Connectivity between kelp populations is reinforced by reproductive synchrony because higher densities of spores in the currents increase the probability of long-distance dispersal (Reed et al., 1997). The seasonal development and demise of visible sori in S. latissima are processes that largely overlap along the south coast of Norway (Andersen et al., 2011; Andersen, 2013). The tight link between the timing of recruitment and these patterns shown by Andersen (2013) support the notion that the potential for connectivity between sugar kelp populations in Norway is high. This may enable forest regeneration by natural recruitment from distant remnant source populations. In fact, kelp recolonization of barren grounds and colonization of artificial reefs far from source populations is consistent with long-distance dispersal of S. latissima.

\section{Regime Shifts or Flips Back and Forth?}

It is now 16 years since the first report on turf algae replacing sugar kelp S. latissima (Moy et al., 2009), then indicating a large spatial scale regime shift along the Norwegian coast. Frigstad et al. (2013) suggested the period close to the millennium shift to be a period of regime shift also in the pelagic ecosystems, which coincides with the shift from sugar kelp to turf. Although there have been considerable reductions in the abundance and spatial distribution of sugar kelp in southern Norway and these forests have been classified as endangered (Skagerrak) and vulnerable (North Sea) on the Norwegian red list for ecosystems and habitat types (Lindgaard and Henriksen, 2011), the species still occur and even recover in large areas along these coastlines.

The data presented here show that sugar kelp may quickly colonize and recover in areas taken over and dominated by turf algae. The sugar kelp, with its high recruitment potential and efficient dispersal of spores during winter (when ephemeral algae are reduced) have a large opportunity to seed new sporophytes and to grow dense populations on available substrate each spring. This may become a new long-lasting sugar kelp bed, or a bed of short duration (months, few years) depending on the amount of epiphytic growth, kelp mortality, and turf algae formation. The kelp recovery may not only vary on a temporal scale, but can also be discontinuous on a spatial scale (see Table 1). Our data 
show that seafloor areas covered by turf and loaded with sediments may persist, and local regime shifts may occur, but also that the positive feedback mechanisms of turf (see FilbeeDexter and Wernberg, 2018) may be challenged. It is not clear which disturbance factors that occur mainly during the winter season and that make the substrate available for new kelp spore settlement. Many turf /ephemeral algae die and disappear during the autumn/winter season (e.g., Moy and Christie, 2012), and rough winter storms and whiplash effects of remaining kelps may sweep away both remaining turf and sediments (Russell, 2007).

In a scenario of further ocean warming, increasing eutrophication, and water darkening (Aksnes et al., 2009; Moy et al., 2009; Frigstad et al., 2013), the conditions will likely, gradually and additionally favor the turf at the expense of S. latissima. How increased ocean temperatures will work together with acidification and high levels of nutrient to impact macroalgae (Connell et al., 2008; Gorman et al., 2009; Falkenberg et al., 2013) is not fully understood. Even if temperature is more favorable for the sugar kelps in deeper parts of their depth distribution, Andersen et al. (in press) described a scenario with decreased light and increased respiration to squeeze the kelps' vertical distribution to shallow areas, leaving reduced seafloor areas as suitable. So far exposure to critical surface temperatures, reduced light, and increased competition from epiphytic and understory turf growth, sugar kelps remains and have been able to recover. There are still healthy sugar kelps close to the surface in Oslofjord at 10. August, 2018 (own observations) although 2018 has been the "warmest summer ever" in southern Norway, with more than 2 months of surface water temperature at or exceeding the critical level of this species (Luning, 1984; Müller et al., 2009) (temperatures higher than $20^{\circ} \mathrm{C}$ from end of May to early August, and even longer periods at $22-23^{\circ} \mathrm{C}$, shown by regular temperature measurements at NIVA's research station).

\section{CONCLUSION}

As sugar kelp have a potential of wide distribution along large parts of the coastline in southern Norway, as well as covering a depth range of $0-25 \mathrm{~m}$, small scale mitigation actions will likely have limited effect. The chance of restored kelps to survive will depend on the growth condition of turfs and epiphytes. On the other hand, the chance of natural restoration of kelps will also depend on available substrate. In years with good conditions for kelp dispersal and restoration, as indicated from Table 1, the natural recolonization of sugar kelp may be much more efficient than any local mitigation action. Kraufvelin et al. (2006) showed restoration of perennial algae when nutrient supplies were reduced, and Lefcheck et al. (2018) presented how long-term nutrient reductions improve large coastal regions. Improving

\section{REFERENCES}

Aksnes, D. L., Dupont, N., Staby, A., Fiksen, Ø, Kaartvedt, S., and Aure, J. (2009). Coastal water darkening and implications for mesopelagic regime shifts in Norwegian fjords. Mar. Ecol. Prog. Ser. 387, 39-49. doi: 10.3354/meps 08120 coastal water quality (eutrophication, browning) will probably be the most important mitigation action. However, if larger areas are totally depleted and a regime shift to turf seems irrevocable, adult sugar kelps may be transplanted to ensure a spore source in the area to enable kelp recovery if conditions seems satisfactory. This paper highlights a complex spatial and temporal distribution pattern between sugar kelp and turf algae, and do not speculate on physical, chemical and biological factors that contribute to create these patterns. Further multifaceted research projects are needed to reveal the causes to the complex patters of kelp-turf distribution presented here.

Both in northern Norway, at the west coasts of South and North America, and at the west African coast kelp beds are persistent and no turf are reported to disturb this persistence. When it comes to NE America, Australia, and Europe, regime shifts from kelp to turf have been reported, also in areas where S. latissima is the dominating kelp (Filbee-Dexter et al., 2016; Filbee-Dexter and Wernberg, 2018). In Norway the sugar kelp has been reported to be far more efficient when it comes to dispersal and colonization than Laminaria spp (Leinaas and Christie, 1996), and may by its opportunistic traits be more able to quickly take advantage of any space available. Thus, our data from the S. latissima areas of the south coast of Norway differ from the systems where persistent regime shifts from kelps to turf occur, although turf seems to persist at some areas also in southern Norway.

\section{AUTHOR CONTRIBUTIONS}

All authors discussed the scope, agreed on the hypothesis and aims of the paper, and contributed to writing the manuscript. HG, TB, CF, and JG produced the most recent data, Figure 3, and Table 1. HC, GA, CF, JG, and ER have many years of experience in the field of collecting data used in this manuscript.

\section{FUNDING}

Most studies were funded by the Norwegian Environment Agency and the data can be used without conflict of interest. Some of the data were produced with funding from the Research Council of Norway, with extra support from NIVA.

\section{ACKNOWLEDGMENTS}

We are grateful for the effort of Frithjof Moy (former NIVA, now Institute of Marine Research) and Lise Ann Tveiten (NIVA) during the early years of the Sugar kelp project.

Andersen, G. S. (2013). Patterns of Saccharina latissima recruitment. PLoS One 8:e81092. doi: 10.1371/journal.pone.0081092

Andersen, G. S., Steen, H., Moy, F., Christie, H., and Fredriksen, S. (2011). Seasonal patterns of sporophyte growth, fertility, fouling and mortality of Saccharina latissima in Skagerrak, Norway - implications for re-forestation. J. Mar. Biol. 2011, 1-8. doi: 10.1155/2011/690375 
Andersen, G. S., Christie, H., and Moy, F. E. (in press). In a squeeze: epibiosis may affect the distribution of kelp forests. Ecol. Evol. doi: 10.1002/ece3.4967

Araujo, R. M., Assis, J., Airoldi, L., Barbara, I., Bartsch, I., Bekkby, T., et al. (2016). Status, trends and drivers of kelp forests in Europe: an expert assessment. Biodivers. Conserv. 25, 1319-1348. doi: 10.1007/s10531-016-1141-7

Bartsch, I., Wiencke, C., Bischof, K., Buchholz, C. M., Buck, B. H., Eggert, A., et al. (2008). The genus Laminaria sensu lato: recent insights and developments. Eur. J. Phycol. 43, 1-86. doi: 10.1080/09670260701711376

Bekkby, T., and Moy, F. E. (2011). Developing spatial models of sugar kelp (Saccharina latissima) potential distribution under natural conditions and areas of its disappearance in Skagerrak. Estuar. Coast. Shelf Sci. 95, 477-483. doi: 10.1016/j.ecss.2011.10.029

Christie, H. (2011). Runde Reef in Hammerfest 2006-2010. NIVA Report to local authorities (Norway: NIVA).

Christie, H., Gundersen, H., Rinde, E., Filbee-Dexter, K., Norderhaug, K. M., Pedersen, T., et al. (2019). Can multitrophic interactions and ocean warming influence large-scale kelp recovery? Ecol. Evol. doi: 10.1002/ece3.4963 [Epub ahead of print].

Cie, D. K., and Edwards, M. S. (2011). Vertical distribution of kelp zoospores. Phycologia 50, 340-350. doi: 10.2216/10-48.1

Cloern, J. E. (2001). Our evolving conceptual model of the coastal eutrophication problem. Mar. Ecol. Prog. Ser. 210, 223-253. doi: 10.3354/meps210223

Connell, S. D., Russell, B. D., Turner, D. J., Shepherd, S. A., Kildea, T., Miller, D. J., et al. (2008). Recovering a lost baseline: missing kelp forests from a metropolitan coast. Mar. Ecol. Prog. Ser. 360, 63-72. doi: 10.3354/meps07526

Duarte, C. M. (1995). Submerged aquatic vegetation in relation to different nutrient regimes. Ophelia 41, 87-112. doi: 10.1080/00785236.1995.10422039

Fagerli, C. W., Naustvoll, L. J., Trannum, H. C., Gitmark, J. K., Norderhaug, K. M., Kile, M. R., et al. (2017). ØKOKYST - Subprogram Rogaland. 2016 Report. 728(Norway: NIVA).

Falkenberg, L. J., Russell, B. D., and Connell, S. D. (2013). Contrasting resource limitations of marine primary producers: implications for competitive interactions under enriched CO2 and nutrient regimes. Oecologia 172, 575-583. doi: $10.1007 / \mathrm{s} 00442-012-2507-5$

Filbee-Dexter, K., Feehan, C. J., and Scheibling, R. E. (2016). Large-scale degradation of a kelp ecosystem in an ocean warming hotspot. Mar. Ecol. Prog. Ser. 543, 141-152. doi: 10.3354/meps11554

Filbee-Dexter, K., and Wernberg, T. (2018). Rise of turfs: a new battlefront for globally declining kelp forests. Bioscience 68, 64-76. doi: 10.1093/biosci/bix147

Frigstad, H., Andersen, T., Hessen, D. O., Jeansson, E., Skogen, M., Naustvoll, L.-J., et al. (2013). Long-term trends in carbon, nutrients and stoichiometry in Norwegian coastal waters: evidence of a regime shift. Prog. Oceanogr. 111, 113-124. doi: 10.1016/j.pocean.2013.01.006

Gaylord, B., Reed, D. C., Raimondi, P. T., and Washburn, L. (2006). Macroalgal spore dispersal in coastal environments: mechanistic insights revealed by theory and experiment. Ecol. Monogr. 76, 481-502. doi: 10.1890/0012-9615(2006) 076[0481:MSDICE]2.0.CO;2

Gorman, D., Russell, B. D., and Connell, S. D. (2009). Land-to-sea connectivity: linking human-derived terrestrial subsidies to subtidal habitat change on open rocky coasts. Ecol. Appl. 19, 1114-1126. doi: 10.1890/08-0831.1

Graham, M. H. (2003). Coupling propagule output to supply at the edge and interior of a giant kelp forest. Ecology 84, 1250-1264. doi: 10.1890/00129658(2003)084[1250:CPOTSA]2.0.CO;2

Gundersen, H., Christie, H., deWit, H., Norderhaug, K. M., Bekkby, T., and Walday, T. (2011). CO2 Uptake in Marine Habitats - An Investigation. NIVA Report 6070-2010 (Norway: NIVA).

Hoffmann, A. J., and Santelices, B. (1991). Banks of algal microscopic forms: hypotheses on their functioning and comparisons with seed banks. Mar. Ecol. Prog. Ser. 79, 185-194. doi: 10.3354/meps079185

Husa, V., Steen, H., and Sjøtun, K. (2014). Historical changes in the macroalgal communities in Hardangerfjord. Mar. Biol. Res. 10, 226-240. doi: 10.1080/ 17451000.2013 .810751

Isaeus, M. (2004). Factors Structuring Fucus Communities at Open and Complex Coastlines in the Baltic Sea. Ph. D thesis Department of Botany, Stockholm University, Sweden.

Kraufvelin, P., Moy, F. E., Christie, H., and Bokn, T. L. (2006). Nutrient addition to experimental rocky shore communities revisited: delayed responses, rapid recovery. Ecosystems 9, 1076-1093. doi: 10.1007/s10021-005-0188-1
Krumhansl, K. A., Okamoto, D. K., Rassweiler, A., Novak, M., Bolton, J. J., Cavanaugh, K. C., et al. (2016). Global patterns of kelp forest change over the past half century. Proc. Natl. Acad. Sci. U.S.A. 113, 13785-13790. doi: 10.1073/ pnas. 1606102113

Lefcheck, J. S., Orth, R. J., Dennison, W. C., Wilcox, D. J., Murphy, R. R., Keisman, J., et al. (2018). Long-term nutrient reductions lead to the unprecedented recovery of a temperate coastal region. Proc. Natl. Acad. Sci. U.S.A. 115, 3658-3662. doi: 10.1073/pnas.1715798115

Leinaas, H. P., and Christie, H. (1996). Effects of removing sea urchins (Strongylocentrotus droebachiensis): stability of the barren state and succession of kelp forest recovery in the east atlantic. Oecologia 105, 524-536. doi: 10.1007/ BF00330016

Lindgaard, A., and Henriksen, S. (eds) (2011). The 2011 Norwegian Red List for Ecosystems and Habitat Types. Trondheim: Norwegian Biodiversity Information Centre.

Luning, K. (1984). Temperature tolerance and biogeography of seaweeds: the marine algal flora of Helgoland (North Sea) as an example. Helgol. Meeresunters. 38, 305-317. doi: 10.1007/BF01997486

Moy, F., Alve, E., Bogen, J., Christie, H., Green, N., Helland, A., et al. (2006). Statusrapport nr. 1-2006 fra Sukkertareprosjektet. Sugar kelp project: Status Report no 1. SFT Report TA-2193/2006, NIVA Report 5265 (Norway: NIVA).

Moy, F., Christie, H., Alve, E., and Steen, H. (2008). Status Report No. 3 From the Sugar Kelp Project. NIVA report 5585. (Norway: NIVA).

Moy, F., Christie, H., Steen, H., Stålnacke, P., Aksnes, D., Alve, E., et al. (2009). Sluttrapport Fra Sukkertareprosjektet 2005-2008. Final report from the Sugar Kelp Project 2005-2008. SFT report TA-2467/2008, NIVA report 5709 (Norway: NIVA).

Moy, F., Christie, H., and Tveiten, L. (2007). Sugar Kelp Investigation in Hardangerfjordenby Juli 2007. NIVA Report 5509. (Norway: NIVA).

Moy, F. E., and Christie, H. (2012). Large scale shift from sugar kelp (Saccharina latissima) to ephemeral algae along the south and west coast of Norway. Mar. Biol. Res. 8, 309-321. doi: 10.1080/17451000.2011.637561

Moy, F. E., Trannum, H. C., Naustvoll, L. J., Fagerli, C. W., and Norderhaug, K. M. (2017). Økokyst Subprogram Skagerrak. Annual Report 2016. Miljødirektoratet M-727. (Norway: NIVA).

Müller, R., Laepple, T., Bartsch, I., and Wiencke, C. (2009). Impact of oceanic warming on the distribution of seaweeds in polar and cold-temperate waters. Bot. Mar. 52, 617-638. doi: 10.1515/BOT.2009.080

Naustvoll, L. J., Moy, F., Dolven, J., and Norderhaug, K. M. (2018). ØKOKYST Sub-program Climate, Miljødirektoratet. Report M1015 (Norway: NIVA).

Nixon, S. W. (1995). Coastal marine eutrophication: a definition, social causes, and future concerns. Ophelia 41, 199-219. doi: 10.1080/00785236.1995. 10422044

O’Brien, J. M., and Scheibling, R. E. (2018). Turf wars: competition between foundation and turf-forming species on temperate and tropical reefs and its role in regime shifts. Mar. Ecol. Prog. Ser. 590, 1-17. doi: 10.3354/meps 2530

Pihl, L., Svenson, A., Moksnes, P. O., and Wennehage, H. (1999). Distribution of green algal mats throughout shallow soft bottoms of the Swedish Skagerrak archipelago in relation to nutrient sources and wave exposure. J. Sea Res. 41, 281-295. doi: 10.1016/S1385-1101(99)00004-0

Pinheiro, J., Bates, D., DebRoy, S., Sarkar, D., and R Development Core Team (2012). Nlme: Linear and Nonlinear Mixed Effects Models. R Package Version 3.1-103. Available at https://cran.r-project.org/web/packages/nlme/.

Reed, D. C., Anderson, T. W., Ebeling, A. W., and Anghera, M. (1997). The role of reproductive synchrony in the colonization potential of kelp. Ecology 78 , 2443-2457. doi: 10.1890/0012-9658(1997)078[2443:TRORSI]2.0.CO;2

Rinde, E., Christie, H., Fagerli, C. W., Bekkby, T., Gundersen, H., Norderhaug, K. M., et al. (2014). The influence of physical factors on kelp and sea urchin distribution in previously and still grazed areas in the NE Atlantic. PLoS One 9:e0100222. doi: 10.1371/journal.pone.0100222

Russell, B. D. (2007). Effects of canopy-mediated abrasion and water flow on the early colonisation of turf-forming algae. Mar. Freshw. Res. 58, 657-665. doi: 10.1071/MF06194

Schiel, D. R., and Foster, M. S. (2006). The population biology of large brown seaweeds: ecological consequences of multiphase life histories in dynamic coastal environments. Annu. Rev. Ecol. Evol. Syst. 37, 343-372. doi: 10.1146/ annurev.ecolsys.37.091305.110251 
Schramm, W. (1999). Factors influencing seaweed responses to eutrophication: some results from EU-project EUMAC. J. Appl. Phycol. 11, 69-78. doi: 10.1023/ A:1008076026792

Sjøtun, K., Husa, V., Asplin, L., and Sandvik, A. D. (2015). Climatic and environmental factors influencing occurrence and distribution of macroalgae - a fjord gradient revisited. Mar. Ecol. Prog. Ser. 532, 73-88. doi: $10.3354 /$ meps 11341

South, P. M., Floerl, O., Forrest, B. M., and Thomsen, M. S. (2017). A review of three decades of research on the invasive kelp Undaria pinnatifida in Australia: an assessment of its success, impacts and status as one of the world's worst invaders. Mar. Environ. Res. 131, 243-257. doi: 10.1016/j.marenvres.2017. 09.015

Steneck, R. S., Leland, A., McNaught, D. C., and Vavrinec, J. (2013). Ecosystem flips, locks, and feedbacks: the lasting effects of fisheries on maine's kelp forest ecosystem. Bull. Mar. Sci. 89, 1-25. doi: 10.5343/bms.2011. 1148

Valiela, I., McClelland, J., Hauxwell, J., Behr, P. J., Hersh, D., and Foreman, K. (1997). Macroalgal blooms in shallow estuaries: controls and ecophysiological and ecosystem consequences. Limnol. Oceanogr. 42, 1105-1118. doi: 10.4319/lo.1997.42.5_part_2.1105

Waycott, M., Duarte, C. M., Carruthers, T. J. B., Orth, R. J., Dennison, W. C., Olyarnik, S., et al. (2009). Accelerating loss of seagrass across the globe threatens coastal ecosystems. Proc. Natl. Acad. Sci. U.S.A. 106, 12377-12381. doi: 10.1073/ pnas.0905620106

Conflict of Interest Statement: The authors declare that the research was conducted in the absence of any commercial or financial relationships that could be construed as a potential conflict of interest.

Copyright (c) 2019 Christie, Andersen, Bekkby, Fagerli, Gitmark, Gundersen and Rinde. This is an open-access article distributed under the terms of the Creative Commons Attribution License (CC BY). The use, distribution or reproduction in other forums is permitted, provided the original author(s) and the copyright owner(s) are credited and that the original publication in this journal is cited, in accordance with accepted academic practice. No use, distribution or reproduction is permitted which does not comply with these terms. 